DOI: http://dx.doi.org/10.33846/hn31205

http://heanoti.com/index.php/hn

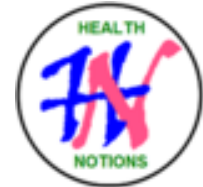

RESEARCH ARTICLE

URL of this article: http://heanoti.com/index.php/hn/article/view/hn31205

\title{
Correlation Between Protein, Calcium and Zinc Intake with Stunting in Children Age 3-5 Years Old in Gubeng, Mojo, Surabaya
}

\author{
Ayuning Tetirah Ramadhani ${ }^{1(\mathrm{CA})}$, Widati Fatmaningrum², Roedi Irawan $^{3}$ \\ ${ }^{1(\mathrm{CA})}$ Faculty of Medicine, Universitas Airlangga, Indonesia; tetiraa@ yahoo.com (Corresponding Author) \\ ${ }^{2}$ Department of Public Health, Faculty of Medicine, Universitas Airlangga, Indonesia; \\ widatifatmaningrum@yahoo.com \\ ${ }^{2}$ Department of Pediatric Health, Faculty of Medicine, Universitas Airlangga, Indonesia; \\ roedi.irawan@fk.unair.ac.id
}

\begin{abstract}
Stunting is a condition that occurs as the result of the disruption in the growth of height due to poor nutrition intake and nutrition status, repeated incidence of infection and inadequate psychosocial stimulation. In year 2017 , the prevalence status for stunting incindence in Indonesia is categorized as high, reaching at 29,6\%. This study was conducted to determine the correlation between nutritional intake of protein, calcium and zinc with the incidence of stunting. This study was an observational analytic research with a case control method, conducted to determine the correlation between exposure of risk factors and disease by comparing stunting groups with non-stunting groups. This study obtained a relation between depleted calcium intake and stunting incidence using the Fisher's Exact test with a p value of 0.001 and odd ratio 0.056. A significant correlation of insufficient calcium intake with the incidence of stunting was found, yet there were no correlation between insufficient protein and zinc intake with the incidence of stunting.
\end{abstract}

Keywords: stunting; protein; calcium; zinc

Background

INTRODUCTION

According to the World Health Organization in 2013, Indonesia was ranked the world's 25th highest stunting prevalence for children under the age of 5. The WHO also stated that the maximum tolerable point for stunting prevalence to be categorized as severe is at $30-39 \%$ and at $40 \%>$ to be categorized as overly severe ${ }^{(1)}$. According to a study conducted in 2012 regarding nutritional status, it was stated that children with stunted bodies can be identified using the WHO's Child Growth Standard, with z-scores for H/A is lower than <-2 $\mathrm{SD}^{(2)}$. According to a study conducted in 2015 , it was stated that body growth in children required certain nutrient components appertaining macronutrient components and micronutrient components. Macro components mentioned involving carbohydrates, protein, and fat, whereas micro components involving many kinds of vitamins and minerals, which includes calcium, iron, zinc, etc. Important components pertinent to bone growth includes proteins, calcium minerals and zinc minerals ${ }^{(3)}$.

Protein provides kinds of amino acids that are needed for the growth of bone tissue, especially in the process of remodeling and increasing bone mass. Protein, being one of the the macronutrient component in bone growth, also provide sources of energy to be included in the biological process of producing energy with carbohydrates and $\mathrm{fat}^{(4)}$. The proteins that are consumed consists of 9 essential amino acids (tryptophan, phenylalanine, histidine, isoleucine, leucine, methionine, valine, threonine, lysine) that have the important function in body growth ${ }^{(5)}$. The said amino acids are categorized as essentials because the human body cannot produce them by themselves, so active consumption of protein in the form of diets is needed. Essential amino acids that has a role in bone growth and remodeling can also be called aromatic amino acids, which includes phenylalanine, tyrosine and tryptophan. Aromatic amino acids can modulate the production of IGF-1 to be increased in the body, including in growth plates where the acids can support the process of differentiation and 
proliferation of chondrocytes and osteoblasts. IGF-1 can also increase the absorption of calcium and phosphor in bones by converting 25 hydroxyl-vitamin $\mathrm{D}_{3}$ into an active hormone of 1,25 dihydroxyl-vitamin $\mathrm{D}_{3}{ }^{(4)}$.

Calcium is one of the key components of micronutrients that are needed for bone growth in children. Lack of calcium levels in the body can affect the linear growth in children if the contents of calcium is below than $50 \%$ the normal determined value of calcium inside the system. This condition correlates with the important function of calcium in the process of bone mineralization and also bone health, especially the process of formation and preservation of bone structure and bone rigidity. Therefore, adequate calcium intake has an important role in the growth of children mainly when entering the peak bone mass period ${ }^{(6)}$.

Calcium undertakes the process of bonding with phosphate which is located in the extracellular fluid and carried out together through the blood vessels until deposited in bones in the form of crystalline molecules or hydroxyapatite crystals $\left(\mathrm{Ca}_{10}\left(\mathrm{PO}_{4}\right)_{6}(\mathrm{OH})_{2}\right)$. This bond is regulated by the 1,25 dihydroxyl-vitamin $\mathrm{D}_{3}$ hormone in the metabolism process, so that the lacking value of phosphor and vitamin D inside the body can also affect the process of bone growth ${ }^{(4)}$.

Other micronutrient components including zinc minerals, an important element that is needed in low concentration but is considered essential. According to a study conducted in 2012, it was concluded that zinc intake prevalence that was inadequate reached the point of 7,5\% in developed countries and $30 \%$ in Southeast Asia. The prevalence had a correlation with the prevalence of stunting incidence especially in children under 5 years of age. ${ }^{(7)}$

Zinc are found in high value throughout bone tissues, compared to other tissues inside the body. This phenomenon is related to zinc's function of helping the bone to maintain the strength of the bone matrix. Inside the body, zinc interacts with osteocalcine hormone and IGF-1, which sometimes be known as somatomedin-C. Osteocalcine is one of the non-collagen proteins that are found in high number in bone growth components including osteoblast, which will then be excreted by the osteoblast and used in the process of bone formation and mineralization of bone matrix. Osteocalcine can be used as a marker of osteoblast activity such as differentiation. ${ }^{(8)}$

Zinc can promote bone growth through the increase of protein synthesis and cell replication, which will then be of contribution in the process of accumulating new tissues. ${ }^{(9)}$ Low zinc intake can have an effect in a child's body growth, since it has some relations with the process of synthesis and replication. The WHO also stated that taking zinc supplements is one of the on hand efforts to overcome the incidence of stunting. This also correlates with its function to promote linear growth, especially in children with stunted bodies. ${ }^{(10)}$

\section{METHODS}

This research was an observational analytic study that compared two different groups differing in stunting and non-stunting. This research used a case control approach that studied the correlation between exposure and disease. This research took up the correlation between protein, calcium and zinc intake with the incidence of stunting in a single population at a point time approach. The population in this research involved children, age ranging from 3-5, that were enlisted at Mojo's Public Health Center, Surabaya. The sample that were registered as respondents in this study were the enlisted children in the Family Planning and Integrated Health Services Post that works under the monitor of Mojo's Public Health Center, Surabaya. The sample was gathered using the non-probability technique with a purposive sampling approach from the monthly Family Planning and Integrated Health Services Post data ranging from the month of August to December of 2018 in Mojo District, Surabaya.

The data that was observed contains the children's age in a monthly unit and the children's height in a centimeter unit. The data was collected from 12 individual files taken from the total of 44 files, differing from each public health posts of the Family Planning and Integrated Health Services Post in Mojo District under the monitor of Mojo's Public Health Center, Surabaya. Results of daily food intakes as the primary data in this study were gathered by filling out questionnaire papers containing 24-hour food recall table that were given to the candidates of this research, aiming to specifically register variables that were going to be used in this study (protein, calcium and zinc).

The specific measure of the daily protein, calcium and zinc intake were obtained by admitting data of daily food ingredients to the NutriSurvey for Windows program, aiming to specifically count nutrient levels of protein in grams, calcium and zinc in milligrams, which were then classified as sufficient or insufficient according to the Nutritional Adequacy Rate (NAR) table based on the Regulation of the Minister of Health of the Republic of Indonesia No.75 year 2013.

The analytical technique for the risk factor's data utilized a bivariate analysis with the Pearson ChiSquare test if the data was qualified, or with the Fisher's Exact test if the data was not qualified. The data was processed with analytical statistics using the SPSS for Windows program. The level of significance in this research was stated if the results of the analysis had a smaller value than the significance level $\alpha=5 \%$ or if $p$ $<0.05$. 


\section{RESULTS}

There is a significant correlation between the lack of calcium intake based on Nutrition Adequacy Rate (NAR) per person per day and the incidence of stunting in children aged 3-5 years. As for the protein and zinc variables, no significant relationship was found between the lack of protein and zinc intake based on the Nutrition Adequacy Rate (RDA) per person per day and the incidence of stunting in children aged 3-5 years. The results of the analysis between the variables are listed in Table 1.

\section{Respondent's Characteristics}

The observed characteristics of the respondents were the distribution of age and height for children, and height for parents. The distributed characteristics are mentioned in table 1. See below.

Table 1. Characteristics of children (age and height) and characteristics of parents

\begin{tabular}{cccccccc}
\hline \multirow{2}{*}{ Characteristics } & & Stunting & \multicolumn{4}{c}{ Non stunting } \\
\cline { 2 - 7 } & & Mean \pm SD & $\mathrm{n}$ & $\%$ & Mean \pm SD & $\mathrm{n}$ & $\%$ \\
\hline Age (years old) & $3-4$ & $3.57 \pm 0.22$ & 9 & 60 & $3.59 \pm 0.20$ & 6 & 40 \\
& $>4-5$ & $4.88 \pm 0.19$ & 6 & 40 & $4.40 \pm 0.28$ & 9 & 60 \\
& & Mean \pm SD & Min & Max & Mean \pm SD & Min & Max \\
Children's height $(\mathrm{cm})$ & & $92.93 \pm 3.93$ & 88 & 99 & $104.67 \pm 7.52$ & 95 & 120 \\
Parent's height $(\mathrm{cm})$ & Mother & $151.93 \pm 6.45$ & 143 & 160 & $155.06 \pm 3.76$ & 147 & 160 \\
& Father & $161.93 \pm 7.2$ & 150 & 170 & $165.93 \pm 7.30$ & 155 & 185 \\
\hline
\end{tabular}

Based on Table 1, it was found that the characteristics of the children's age in the case and control groups are both at most 3-4 years old and at least >4-5 years old. As for the characteristics of the child's height seen from the minimum and maximum values, the stunting group resulted a minimum value of $88 \mathrm{~cm}$ and a maximum value of $99 \mathrm{~cm}$, while the non-stunting group resulted a minimum value of $95 \mathrm{~cm}$ and a maximum value of $120 \mathrm{~cm}$. Based on Table 1, it was also found that the average height of mothers and fathers in the nonstunting group had a higher value than the mothers and fathers in the stunting group.

Table 2. Characteristics of protein, calcium and zinc intakes and sufficiency

\begin{tabular}{|c|c|c|c|c|c|c|}
\hline \multirow{2}{*}{ Characteristics } & \multicolumn{2}{|l|}{ Stunting } & \multicolumn{4}{|c|}{ Non stunting } \\
\hline & Mean \pm SD & Min & $\operatorname{Max}$ & Mean \pm SD & Min & Max \\
\hline Protein $(\mathrm{g})$ & $54.50 \pm 16.72$ & 19.85 & 79.70 & $95.07 \pm 49.41$ & 43.40 & 258.70 \\
\hline Calcium (mg) & $740.85 \pm 330.23$ & 268.30 & 1253 & $1613.91 \pm 893.23$ & 611.40 & 4498.70 \\
\hline Zinc (mg) & $9.05 \pm 5.36$ & 2.98 & 24.90 & $19.56 \pm 12.57$ & 6.90 & 52.06 \\
\hline \multirow{2}{*}{ Nutrient sufficiency } & Stunting & & \multicolumn{2}{|c|}{ Non Stunting } & Total & \\
\hline & $\mathrm{n}$ & $\%$ & $\mathrm{n}$ & $\%$ & $\mathrm{n}$ & $\%$ \\
\hline \multicolumn{7}{|l|}{ Protein sufficiency } \\
\hline Sufficient & 13 & 13.33 & 15 & 100.00 & 28 & 93.3 \\
\hline Insufficient & 2 & 86.67 & 0 & 0.00 & 2 & 6.7 \\
\hline \multicolumn{7}{|l|}{ Calcium sufficiency } \\
\hline Sufficient & 4 & 26.67 & 13 & 13.33 & 17 & 56.7 \\
\hline Insufficient & 11 & 73.33 & 2 & 86.67 & 13 & 43.3 \\
\hline \multicolumn{7}{|l|}{ Zinc sufficiency } \\
\hline Sufficient & 13 & 13.33 & 15 & 100.00 & 28 & 93.3 \\
\hline Insufficient & 2 & 86.67 & 0 & 0.00 & 2 & 6.7 \\
\hline Total & 30 & 100 & 30 & 100 & 30 & 100 \\
\hline
\end{tabular}

Based on Table 2, it was found that the minimum and maximum value of nutrient intakes in the nonstunting group had a higher value than the minimum and maximum values in the stunting group. Based on Table 2 , it was also found that the average value of nutritional intake in the non-stunting group had a higher outcome than the average value of nutritional intake in the stunting group. The level of nutrient adequacy that are studied in this research are macronutrients, namely protein and micronutrients; calcium and zinc. The data used in this research are primary data obtained through the interview process using the 24-hour food recall questionnaire method, then conducting an analysis of nutrient levels was carried out using the NutriSurvey for Windows program. 
Based on Table 2, it was found that the distribution of the nutritional adequacy value for the stunting group was the same for protein and zinc variable, $86.67 \%$ meeting the sufficient level, and $13.33 \%$ insufficient. For the calcium variable, $26.67 \%$ meeting the sufficient level and $73.33 \%$ insufficient. Based on Table 2, it was also found that the distribution of nutritional adequacy value for the non stunting group was the same for the protein and zinc variable; $100 \%$ sufficient. For the calcium variable, the value reached $86.67 \%$ sufficient and $13.33 \%$ insufficient.

Based on Table 2, it was also found that the distribution of nutritional adequacy value was the same for the protein and zinc variable, $93.3 \%$ meeting the sufficient level and $6.7 \%$ insufficient. For calcium variable, $56.7 \%$ was sufficient and $43.3 \%$ was insufficient.

\section{Correlation Between Protein, Calcium and Zinc Intake Sufficiency With Stunting Incidence}

The analytical result for protein, calcium and zinc intake with the incidence of stunting is laid out in table 3. See below.

Table 3. Correlation of nutrient intake sufficieny with stunting incidence

\begin{tabular}{|c|c|c|c|c|c|c|}
\hline \multirow{2}{*}{ Variables } & \multicolumn{2}{|c|}{ Groups } & \multirow{2}{*}{$\mathrm{n}$} & \multirow{2}{*}{ Chi-Square } & \multirow{2}{*}{ Fisher's exact } & \multirow{2}{*}{ OR } \\
\hline & Stunting & Non stunting & & & & \\
\hline \multicolumn{7}{|l|}{ Protein } \\
\hline - Sufficient & 13 & 15 & 28 & 0.143 & 0.483 & NA \\
\hline - Insufficient & 2 & 0 & 2 & & & \\
\hline \multicolumn{7}{|l|}{ Calcium $^{* *}$} \\
\hline - Sufficient & 11 & 13 & 24 & 0.001 & 0.003 & 0.056 \\
\hline - Insufficient & 4 & 2 & 6 & & & \\
\hline \multicolumn{7}{|l|}{$\operatorname{Zinc}^{* * * *}$} \\
\hline - Sufficient & 13 & 15 & 28 & 0.143 & 0.483 & NA \\
\hline - Insufficient & 2 & 0 & 2 & & & \\
\hline
\end{tabular}

* The analytical technique for this variable was the Fisher's exact test because the data did not meet the Chi square qualifications; there were cells in the $2 \times 2$ table with a reality frequency value of 0 and a number of cells with a frequency value of less than 5 by $20 \%$. A p value of 0.483 was found. This value is greater than the significance level $\alpha=5 \%$, so it can be concluded that H0 is accepted, which means that the protein variable has no significant relationship with the incidence of stunting.

** The analytical technique for this variable was the Chi square test because the data matched the qualifications. A p value of 0.001 was found. This value is smaller than the significance level $\alpha=5 \%$, so it can be concluded that $\mathrm{H} 0$ is rejected, which means that the calcium variable has a significant relationship with the incidence of stunting.

*** The analytical technique for this variable was the Fisher's exact test because it did not meet the Chi square qualifications; there were cells in the $2 \times 2$ table with a reality frequency value of 0 and a number of cells with a frequency value of less than 5 by $20 \%$. A p-value of 0.483 was found. This value is smaller than the significance level $\alpha=5 \%$, so it can be concluded that H0 is accepted, which means that the zinc variable does not have a significant relationship to the incidence of stunting.

\section{DISCUSSION}

Protein is the most important macronutrient component that has a role in height growth by promoting the production and circulation of insulin, IGF-1 and T3, together with amino acids play a role in growth plates or epiphyseal plates in the process of endochondral ossification/secondary ossification/long bone ossification. ${ }^{(11)}$

The results showed no significant relationship between protein intake and stunting. Researchers suspect this phenomenon to happen because most of the protein intake of respondents in the stunting group (86.67\%) and the non-stunting group (100\%) had sufficient nutritional adequacy rates per person per day according to the Minister of Health Regulation of the Republic of Indonesia No. 75 year 2013 for children aged 3-5 years.

These results are in line with the research conducted by Margawati and Astuti in 2018 that concluded no significant relationship between protein intake and the incidence of stunting. ${ }^{(12)}$ This is also supported by the research conducted by Ruslan Ningrat in 2017 that stated no difference between protein intakes in stunting and non-stunting groups. ${ }^{(13)}$

According to a cross sectional study conducted by Setyawati and Faizah in 2012 regarding the relationship of protein intake with nutritional status, it was stated that there was no relationship between protein intake and nutritional status that was allegedly caused by variables that were not included in the study at one time. Some of the variables that were not distributed in the study include infections, parenting system, sanitation, parent's education, and public knowledge for health. In this case, protein is said not to be the sole 
cause of malnutrition, but rather also involving macronutrients other than protein (carbohydrates, fats, vitamins and minerals). ${ }^{(14)}$

Calcium has an important role in the process of bone mineralization, bone matrix deposit and has the ability to affect the role of osteoblasts in the process of bone growth in growth plates during divisio. ${ }^{(15)}$

The results showed a significant relationship between calcium intake and the incidence of stunting in children aged 3-5 years. Researchers suspect the significant correlation between calcium and the incidence of stunting is due to the higher rate of children who do not reach nutritional adequacy for calcium intake per person per day according to the Minister of Health Regulation of the Republic of Indonesia No. 75 year 2013 for children aged 3-5 years.

This statement is supported by a research conducted by Farah et al in 2015 which said that there was a significant relationship between calcium intake and the incidence of stunting. ${ }^{(16)}$ This is also supported by a research conducted by Adhi Wibowo in 2018 which stated that there was a significant relationship between calcium intake and the incidence of stunting. ${ }^{(17)}$

According to a research conducted by Prentice and Bates in 1993, it was said that the lack of calcium intake that reaches $50 \%$ of the adequacy of calcium nutrition will affect linear growth in children. ${ }^{(18)}$ This theory is also supported by a research conducted by Khairy et al in 2010 which stated that the demands of bone mineralization in children are very high, so the deficit in calcium will disrupt the process of bone mineralization and bone mass formation. The low calcium will affect the bone matrix mineralization process due to the low calcium and phosphate bonds that are deposited inside the bone in the form of hydroxyapatite crystals. Calcium and phosphate can be absorbed by the intestine with the help of parathyroid hormone (PTH) secreted by the parathyroid gland, also by the help of vitamin $\mathrm{D}$ in the form calcitriol hormone and calcium regulating hormone along with calcium-sensing receptors. The ratio of calcium and phosphate is vital; calcium: phosphor $=2: 1$ or 1: 1. Lack of calcium levels will eliminate the work of inorganic phosphate in the metabolic process (cells, nucleotides, ATP) and bone mineralization process. ${ }^{(19)}$

Zinc is one of the nutritional components that can trigger the production of insulin growth factor (IGF-1) and increase the work of IGF-1 in height growth. ${ }^{(9)}$

The results showed no significant relationship between zinc intake and the incidence of stunting in children aged 3-5 years. Researchers suspect that because most of the zinc intake of the respondents in the stunting group $(86.67 \%)$ and non-stunting group $(100 \%)$ had sufficient nutritional adequacy rates per person per day according to the Minister of Health Regulation of the Republic of Indonesia No. 75 year 2013 for children aged 3-5 years.

This is supported by a research conducted by Setyawati and Faizah in 2012 which stated that there is no significant relationship between zinc intake and the incidence of stunting in children aged 3-5 years. ${ }^{(14)}$ This is also supported by a research conducted by Anshori in 2013 which stated that there is no significant relationship between zinc intake and the incidence of stunting in children aged 3-5 years. ${ }^{(20)}$

According to research conducted by Margawati and Astuti in 2018, it was said that the process of zinc absorption in the body is influenced by the form of solid zinc or zinc solution. The study said that zinc absorption would be more effective (60-70\%) if the zinc consumed was in a solution. ${ }^{(12)}$. According to research conducted by Saaka and Galaa in 2016, it was said that the process of zinc absorption will be reduced if there is a high concentration of phytate and fiber in the body. ${ }^{(21)}$ The theory is put forward by Hidayat in 1999 about zinc micronutrients on health alludes to the zinc homeostasis system which is influenced by the process of absorption and excretion. The process of homeostasis can occur if zinc intake in the body experiences a deficit in a short period of time, not for a long-term or sustained zinc deficit. The theory states that zinc will adjust to an inadequate diet or lack of zinc intake by changing endogenous zinc in the body into a source of zinc intake. $^{(22)}$

\section{CONCLUSION}

This research found a significant relationship between the incidence of stunting in children aged 3-5 years with the adequacy of nutrients for calcium intake. This is due to the lack of achieving adequate levels of calcium nutrition per person per day for children aged 3-5 years according to the Regulation of the Minister of Health of the Republic of Indonesia No. 75 year 2013. As for the nutritional intake of protein and zinc, no significant relationship was found between the incidence of stunting and the adequacy of nutrients for protein and zinc intake. This is because most of the research subjects have had sufficient levels of protein and zinc nutrition per person per day for children aged 3-5 years according to the Regulation of the Minister of Health of the Republic of Indonesia No.75 of 2013.

\section{REFERENCES}

1. World Health Organization. Global Database of Childhood Growth and Malnutrition: Description [Internet]. WHO. 2018 [cited 2018 Jun 1$]$ Available from: http://www.who.int/nutgrowthdb/about/introduction/en/index5.html 
2. Anugraheni H. Risk factors for stunting in children 12-36 months in Pati, Pati Regency (Faktor risiko kejadian stunting pada anak usia 12-36 bulan di Kecamatan Pati, Kabupaten Pati). Semarang: Universitas Diponegoro; 2012.

3. Harahap H, Sandjaja, Soekatri M. Bone density, physical activity and food consumption associated with stunting in children 6-12 years old (Kepadatan tulang, aktivitas fisik dan konsumsi makanan berhubungan dengan kejadian stunting pada anak usia 6-12 tahun). Gizi Indonesia. 2015;38(1):1-8.

4. Mayang Sari E, Juffrie M, Nurani N, Sitaresmi MN. Intake of protein, calcium and phosphor in stunting and non-stunting children age 24-59 months (Asupan protein, kalsium dan fosfor pada anak stunting dan tidak stunting usia 24-59 bulan). Jurnal Gizi Klinik Indonesia. 2016;12(4):152-9.

5. Semba RD, et al. Child Stunting is Associated with Low Circulating Essential Amino Acids [Internet]. Science $\begin{array}{lllllll}\text { Direct. } & 2016 & \text { [cited } & 2018 & \text { Jun } & 1] & \text { Available }\end{array}$ https://www.sciencedirect.com/science/article/pii/S235239641630069X

6. Bueno AL, Czepielewski MA. The Importance for Growth of Dietary Intake of Calcium and Vitamin D. Journal de Pediatria. 2008;84(5):386-393

7. Wessels KR, Brown KH. Estimating The Global Prevalence Of Zinc Deficiency: Results Based on Zinc Availability in National Food Supplies and The Prevalence of Stunting [Internet]. NCBI. 2012 [cited 2018 Jun 1]. Available from: https://www.ncbi.nlm.nih.gov/pmc/articles/PMC3510072/

8. Anindita P. Correlation of mother's education, family income, adequacy of protein \& zinc with stunting in children age 6-35 months in Tembalang, Semarang (Hubungan tingkat pendidikan ibu, pendapatan keluarga, kecukupan protein \& zinc dengan stunting (pendek) pada balita usia 6-35 bulan di Kecamatan Tembalang Kota Semarang). Jurnal Kesehatan Masyarakat. 2012;1(2):617-626

9. Xuan Ninh N, et al. Zinc Supplementation Increases Growth and Circulating Insuline-like Growth Factor-1 (IGF-1) in Growth Retarded Vietnamese Children. American Society for Clinical Nutrition. 1996;63(5):514-9.

10. World Health Organization. Zinc Supplementation and Growth in Children [Internet]. WHO. 2013 [cited 2018 Jun 1]. Available from: http://www.who.int/elena/bbc/zinc_stunting/en/

11. Millward DJ. Nutrition, Infection and Stunting: The Roles of Deficiencies of Individual Nutrients and Foods, and of Inflammation, as Determinants of Reduced Linear Growth of Children. Nutrition Research Reviews. Cambride University Press. 2017;30(1):50-72.

12. Margawati A, Astuti AM. Mother's education, diet and nutritional status of stunting children age 1-5 years in the Bangetayu Village, Genuk, Semarang (Pengetahuan ibu, pola makan dan status gizi pada anak stunting usia 1-5 tahun di Kelurahan Bangetayu, Kecamatan Genuk, Semarang). Jurnal Gizi Indonesia. 2018;6(2):82-8.

13. Ruslan Ningrat JP. Energy, protein, calcium, iron and phosphor adequacy levels in stunting children in coastal and mountains of Gangga, North Lombok Regency (Tingkat kecukupan energi, protein, kalsium, zat besi dan fosfor pada balita stunting di pesisir dan pegunungan Kecamatan Gangga Kabupaten Lombok Utara). Bogor: Institut Pertanian Bogor; 2017.

14. Setyawati VA, Faizah Z. Correlation between protein, iron, zinc intake with nutritional status of children with malnutrition in the working area of Semarang Health Office (Hubungan antara asupan protein, besi dan seng dengan status gizi pada anak balita gizi buruk di wilayah kerja Dinas Kesehatan Kota Semarang). Jurnal Visikes. 2012;11(1):47-58.

15. Chairunnisa E. Inadequate intake of vitamin D, calcium and phosphor in stunting children from 12-24 months in Semarang (Asupan vitamin D, kalsium dan fosfor inadekuat pada anak stunting usia 12-24 bulan di Kota Semarang). Semarang: Universitas Diponegoro; 2017.

16. Farah OA, Ninna R, Mury R. Factors that influence stunting in children (Faktor-faktor yang mempengaruhi kejadian stunting pada anak). e-Jurnal Pustaka Kesehatan. 2015;3(1):163-170.

17. Adhi Wibowo HK. Correlation of calcium intake and mother's education with stunting incidence in children in Madrasah Ibtidaiyah Muhammadiyah, Kartasura (Hubungan asupan kalsium dan pendidikan ibu dengan kejadian stunting pada anak di Madrasah Ibtidaiyah Muhammadiyah, Kartasura). Universitas Muhammadiyah; 2018.

18. Prentice A, Bates CJ. An Appraisal of the Adequacy of Dietary Mineral Intakes in Developing Countries for Bone Growth And Development In Children. Nutrition Research Reviews. 1993;6(6):51-69.

19. Khairy SAM, Mattar MK, Refaat LAM, El- Sherbeny SA. Plasma Micronutrient Levels of Stunted Egyptian School-Age Children. Kasr El Aini Med J. 2010;16(1):1-5.

20. Anshori H. Risk factors for stunting in children 12-24 months (study in East Semarang District) (Faktor risiko kejadian stunting pada anak usia 12-24 bulan (studi di Kecamatan Semarang Timur)). Semarang: Universitas Diponegoro; 2013.

21. Saaka, M, Galaa, SZ. Relationships Between Wasting and Stunting and Their Concurrent Occurrence in Ghanaian Preschool Children. Journal of Nutrition and Metabolism. 2016:2016:1-12.

22. Hidayat A. The role of zinc nutrition for health and pain (Peranan zat gizi mikro seng bagi kesehatan dan kesakitan). Majalah Ilmiah Fakultas Kedokteran Universitas Trisakti. 1999;18:19-25. 